\title{
Pengaruh Millieu Therapy Metode Kreasi Seni membuat Gelang terhadap Penurunan Kesepian (Loneliness) Lansia
}

\author{
Ah Yusuf, Iqlima Dwi Kurnia, Manis Aero Dwi Noerviana \\ Fakultas Keperawatan, Universitas Airlangga \\ Email: ah-yusuf@fkp.unair.ac.id
}

\begin{abstract}
Abstrak
Kesepian merupakan perasaan terasing dan tersisihkan yang sifatnya subjektif, dimana individu merasa kesepian. Semua lansia tentunya berkeinginan untuk dapat hidup sejahtera dalam masa tuanya bersama anak dan keluarganya dalam rumah sendiri. Namun pada kenyataanya tidak semua lansia dapat mencapai hal tersebut karena berbagai hal seperti karena faktor kemiskinan, tidak mempunya keturunan ataupun keluarga yang dapat merawat lansia serta ketidakmampuan keluarga dalam memberikan perawatan pada lansia, sehingga banyak lansia menjadi terlantar.Tujuan penelitian ini adalah menjelaskan pengaruh millieu therapy metode kreasi seni membuat gelang terhadap penurunan kesepian lansia. Penelitian ini menggunakan pr-experimental one-group pre-post test design. Populasi dalam penelitian ini adalah 76 lansia. Sampel dari penelitian ini 12 responden dengan teknik purposive sampling. Variabel independen dari penelitian ini millieu therapy metode kreasi seni membuat gelang sedangkan variabel dependennya yaitu penurunan kesepian lansia. Pengumpulan data menggunakan lembar kuesioner dan dianalisis dengan menggunakan Uji Wilcoxon Signed Rank Test. Hasil dari penelitian menunjukkan ada pengaruh millieu therapy metode kreasi seni membuat gelang dapat menurunkan kesepian lansia. Uji Wilcoxon Signed Rank Test dengan signifikasinya yaitu $\alpha=0,05$. Uji ini menunjukkan hasil $\alpha=0.035$ yang berarti ada pengaruh millieu therapy metode kreasi seni membuat gelang dapat menurunkan kesepian lansia. Pengaruh millieu therapy metode kreasi seni dapat dijadikan alternatif untuk menurunkan kesepian lansia karena dengan metode kreasi seni lansia dapat menyalurkan kreativitasnya, menghasilkan suatu karya, mengisi waktu luang, dapat bekerja sama satu sama lain dan dapat menstimulasi secara kognitif, afektif, psikomotor, sosio-emosional, dan harga diri. Peneliti juga dapat menggunakan millieu therapy untuk mensupport dan membantu kesepian lansia agar menghasilkan kualitas terbaik di kehidupannya.
\end{abstract}

Kata Kunci: Gelang, kesepian, lansia millieu therapy.

\begin{abstract}
Loneliness is a feelings of isolation where people felling lonely. All the elderly certainly desire to prosper in his old age but the fact isn't all the elderly can reach it due to various reasons such as poverty, currently didn't have offspring or family who can care for the elderly and the inability of the family in providing care to the elderly, so many elderly people become homeless. In this results used preexperimental one-group pre-post test design. The population in this research is elderly with amount 76 people. Sample was 12 people taken by purposive sampling technique. Collected data conducted by using a questionnaire and analyzed used the Wilcoxon Signed Rank Test with significance $\alpha=0.05$. The results of research concluded that millieu therapy methods the creation of art made bracelet could be decreased loneliness of life of the elderly it can stimulate the cognitive, affective, psychomotor, sosio-emotional and self-esteem. Further research is expected to use control groups and researching other factors that influence loneliness the elderly. Researcher can use millieu therapy in supporting and helping the elderly yo live a best quality.
\end{abstract}

Keyword: Bracelet, elderly, loneliness, millieu therapy. 


\section{Pendahuluan}

Lanjut usia adalah seseorang berusia 60 tahun atau lebih (WHO, 2010). Di Indonesia telah terjadi peningkatan jumlah lansia secara dramatis, dengan perkiraan $11,34 \%$ dari keseluruhan populasi penduduk Indonesia pada tahun 2020 dan usia harapan hidup sebesar 71,1 tahun. Semakin terus meningkat populasi maka semakin banyak pula masalah yang terjadi, seperti banyaknya lansia yang tidak berdaya untuk melakukan pekerjaan sehingga tidak memiliki penghasilan, atau bergantung pada orang lain dalam kehidupan sehari-hari.

Semua lansia berkeinginan untuk dapat hidup sejahtera dalam masa tuanya bersama anak dan keluarganya dalam rumah sendiri. Semua bentuk perhatian dan peran aktif keluarga maupun masyarakat akan menimbulkan pengaruh kondusif bagi pemeliharaan kesehatan fisik maupun mental lansia. Namun pada kenyataanya tidak semua lansia dapat mencapai hal tersebut karena berbagai hal seperti karena faktor kemiskinan, tidak mempunya keturunan ataupun keluarga yang dapat merawat lansia serta ketidakmampuan keluarga dalam memberikan perawatan pada lansia, sehingga banyak lansia menjadi terlantar. Berbagai upaya telah dilakukan pemerintah antara lain mendirikan panti wredha untuk memberikan kesejahteraan pada lansia, dengan harapan lansia dapat menikmati hidupnya dengan tentram, aman dan sejahtera.

Selain dampak positif yang ditimbulkan oleh panti, juga terdapat kondisi bahwa didalam panti hubungan antar individu sangat renggang membuat hidupnya terasa sepi. Di dalam panti, semua kegiatan telah diatur dan mobilitas setiap individu dibatasi, dan interaksi sosial terbatas. Terlebih lagi jika hubungan antara lansia dengan keluarganya terputus sama sekali sejak masuk panti, sehingga lansia merasa bahwa hidupnya di panti benar-benar merupakan bentuk isolasi sosial terhadap dirinya. Lansia yang secara sengaja dipindahkan keluarga ke panti wredha diidentifikasi sebagai alasan utama kesepian.

Kesepian adalah suatu keadaan mental dan emosional yang dicirikan oleh adanya perasaan terasing dan ketidakpuasan karena adanya kesenjangan antara hubungan sosial yang diinginkan dengan hubungan sosial yang dimiliki (Brehm, M., Perlman, 2002). Data statistika Indonesia mencatat estimasi angka kesepian, termasuk lima besar negara dengan jumlah penduduk lanjut usia terbanyak di dunia yakni mencapai 18,1 juta jiwa pada 2010 atau 9,6 \% dari jumlah penduduk (Menteri Koordinator Kesejahteraan 
Rakyat RI, 2010). Dengan ini dapat diketahui bahwa semakin meningkatnya jumlah lansia maka angka kesepian pun juga semakin meningkat apabila tidak ditangani dengan baik dan benar. Apabila terjadi peningkatan dampak yang akan terjadi makin banyaknya lansia yang mengalami depresi dan mudah terserang penyakit. Berdasarkan hasil survey awal peneliti tahun 2016 dengan menggunakan lembar kuesioner UCLA dengan 20 item pada lansia di UPTD Griya Wredha Surabaya sebanyak 30 lansia didapatkan 65,2\% lansia merasa kesepian. 25,7\% lansia merasa kadang merasakan kesepian. 10,3\% lansia tidak merasa kesepian.

Seiring dengan pertambahan usia, terjadi perubahan psikosial pada lansia yaitu pensiun, pindah tempat tinggal, menjanda/menduda, identitas sering dikaitkan dengan peranan pekerjaan, sadar akan kematian teman dan keluarga, kehilangan hubungan dengan teman-teman dan keluarga, penyakit kronis \& ketidakmampuan, perubahan terhadap gambaran diri; konsep diri, dan masalah psikologis yang banyak dialami oleh lansia yaitu kesepian (loneliness). Kesepian merupakan suatu keadaan mental dan emosional yang terutama dicirikan oleh adanya perasaan terasing (Padila, 2013). Perubahan mental (psikologi, sosial dan ekonomi) dapat mengakibatkan masalah kesehatan jiwa seperti gangguan cemas, depresi, insomnia, demensia, dan masalah kesepian, duka cita, dan psikosis pada lansia (Depkes RI, 2005, Darmojo, B. D. M., 1999)

Perasaan kesepian dapat dibagi dalam dua jenis yaitu kesepian emosional dan kesepian sosial. Dalam kesepian emosional, seseorang merasa tidak memiliki kedekatan dan perhatian, merasa tidak ada satu orang pun yang peduli terhadapnya, sedangkan kesepian sosial muncul dari kurangnya jaringan sosial dan ikatan komunikasi atau dapat dijelaskan sebagai suatu respon dari tidak adanya ikatan dalam suatu jaringan sosial (Weiss, 1997). Para lansia mengalami perasaan kesepian karena banyak keluarga yang mengabaikan kesejahteraan para lansia dan mereka pun ditinggal sendiri hingga merasa kesepian. Di samping itu, peningkatan jumlah lansia ini seharusnya ada peningkatan kualitas hidup (Widyati,d., Yusuf, a., Fitriyasari, 2014), tidak sekedar tua, tapi juga berkualitas (Akbar, H., 2014).

Millieu Therapy adalah sebuah perencanaan lingkungkan perawatan dimana kejadian dan interaksi setiap hari dirancang secara terapetik dengan tujuan meningkatkan ketrampilan sosial, membangun rasa percaya diri dan meningkatkan 
harga diri (Aronson, E., wilson t. D., \& akert, 2010). Terapi lingkungan dapat meningkatkan pengalaman positif pada pasien dengan cara membantu individu dalam mengembangkan harga diri, menumbuhkan sikap percaya pada orang lain, mempersiapkan diri kembali ke masyarakat, dan mencapai perubahan yang positif (Stuart, G. W., 1998). Beberapa jenis kegiatan terapi lingkungan yaitu terapi rekreasi, terapi kreasi seni, terapi dengan menggambar dan melukis, literatur atau bibliotherapy, pet therapy, dan plant therapy. Peneliti memilih jenis metode kreasi seni dengan membuat gelang dari tali karena pasien dapat melakukan kegiatan secara konstruktif dan menyenangkan serta mengembangkan kemampuan hubungan sosial. Dalam kehidupan sehari-hari seni digunakan untuk menggambarkan rasa cinta, kasih sayang, dan keindahan. Kelebihan dan keuntungan dari metode kreasi seni ini lansia dapat menyalurkan kreatifitasnya, menciptakan suatu hasil karya, mengisi waktu luang, dan dapat bekerja sama untuk melakukan suatu hasil karya.

Terapi lingkungan metode kreasi seni mampu mengisi waktu luang pasien dengan memotivasi pasien ikut serta dalam aktivitas lingkungan yang sesuai dengan minat, kemampuan, dan tingkat perkembangannya (Yusuf, Fitrasari, Nihayati, 2015). Kreasi seni membuat gelang dapat melatih kesabaran, ketelitian, kreativitas, kerjasama dengan yang lain, dan keuletan pada lansia. Berdasarkan uraian diatas dan melihat fenomena yang terjadi, maka bermaksud meneliti pengaruh millieu therapy dengan metode kreasi seni membuat gelang terhadap penurunan kesepian lansia.

\section{Metode}

Desain penelitian menggunakan Pra Eksperimental dengan metode One Group PrePost Design. Sampel berjumlah 12 responden yang dibagi dalam 3 kelompok dengan 4 responden tiap kelompok. Cara pengambilan sampel menggunakan purposive sampling yaitu memilih sampel diantara populasi sesuai dengan kriteria penelitian, yaitu; tinggal di griya wredha, mengalami kesepian, kooperatif, bersedia menjadi responden. Variabel independen adalah Millieu Therapy metode kreasi seni dengan membuat gelang dan variabel dependen adalah penurunan kesepian (loneliness) pada lansia. Instrumen yang digunakan yaitu kuisioner UCLA.

Data yang telah terkumpul dianalisis dengan uji wilcoxon signed rank test untuk membandingkan data ordinal pre test dan post test intervensi. Uji statistik menggunakan 
tingkat signifikasi $\alpha=0,05$, yang artinya bila nilai $\alpha \leq 0,05$ maka ada perbandingan data sebelumnya dan setelah dilakukan intervensi terhadap kesepian lansia. Data hasil analisis kemudian ditampilkan dalam bentuk tabel.

\section{Hasil}

Hasil deskripsi demografi menunjukkan bahwa responden terbanyak pada kelompok usia 70-79 tahun sebanyak 7 lansia (58\%), berjenis kelamin perempuan (67\%), tidak sekolah (42\%) yang paling lama di panti yaitu 0-5 tahun (67\%) dan aktivitas sehari-hari mengisi waktu luang yang paling banyak dilakukan yaitu tidur (67\%). (Tabel 1)

Tabel 1 Karakteristik Demografi Responden $(n=12)$

\begin{tabular}{llcc}
\hline Data Demografi & Kategori & f & \% \\
\hline Umur & $60-65$ & 4 & $33 \%$ \\
& $66-70$ & 1 & $8 \%$ \\
& $71-75$ & 2 & $17 \%$ \\
& $76-80$ & 5 & $42 \%$ \\
\hline Jenis Kelamin & Laki-laiki & 4 & $33 \%$ \\
& Perempuan & 8 & $67 \%$ \\
\hline Pendidikan & Tidak Sekolah & 5 & $42 \%$ \\
& SD & 4 & $33 \%$ \\
& SMP & 1 & $8 \%$ \\
& SMA & 2 & $17 \%$ \\
& Perguaruan Tinggi & 0 & $0 \%$ \\
\hline Mentivitas Sehari-hari & 1 = Menonton TV & 2 & $17 \%$ \\
& 2= Tidur & 7 & $58 \%$ \\
Lama Menghuni & 3= Mengobrol dengan Teman & 3 & $25 \%$ \\
& 0-5 Tahun & 8 & $67 \%$ \\
& 5-10 Tahun & 4 & $33 \%$ \\
& $>10$ Tahun & 0 & $0 \%$ \\
\hline
\end{tabular}

Karakteristik berdasarkan data makna hidup sebelum diberikan terapi menunjukkan jumlah lansia yang mengalami kesepian sedang sebanyak 6 lansia (50\%) sedangkan kesepian lansia sesudah diberikan millieu therapy metode kreasi seni membuat gelang di UPTD Griya Wredha Surabaya yang mengalami kesepian rendah sebanyak 9 lansia (75\%). (Tabel 2)

Tabel 2 Kesepian lansia sebelum dan setelah dilakukan intervensi

\begin{tabular}{clcc}
\hline Kesepian & \multicolumn{1}{c}{ Kategori } & f & \% \\
\hline \multirow{5}{*}{ Pre test } & Tidak Kesepian & 1 & $8 \%$ \\
& Kesepian Rendah & 5 & $42 \%$ \\
& Kesepian Sedang & 5 & $42 \%$ \\
& Kesepian Tinggi & 1 & $8 \%$ \\
\hline Post test & Tidak Kesepian & 2 & $17 \%$
\end{tabular}




\begin{tabular}{llc}
\hline Kesepian Rendah & 9 & $75 \%$ \\
Kesepian Sedang & 1 & $8 \%$ \\
Kesepian Tinggi & 0 & $0 \%$ \\
\hline
\end{tabular}

Hasil uji statistik Wilcoxon Sign Rank Test menunjukkan hasil $p=0,035<\alpha$ yang bermakna $\mathrm{H}_{0}$ ditolak dan $\mathrm{H} 1$ diterima, sehingga ada pengaruh millieu therapy metode kreasi seni membuat gelang terhadap penurunan kesepian lansia.

\section{Pembahasan}

Kesepian lansia sebelum diberikan intervensi, responden sebagian besar (42\%) menunjukkan kesepian sedang yaitu responden merasa tidak mempunyai teman dekat, merasa tidak mempunyai tempat berbagi, merasa sendirian, merasa tidak seorangpun dekat dengannya, merasa dijauhkan, dan merasa malu dengan orang sekitar. Terdapat 1 responden masih ditemukan dengan kesepian yang tinggi. Kesepian lansia yang tinggi dipengaruhi oleh jenis kelamin, tingkat pendidikan, dan aktivitas.

Kesepian merupakan perasaan yang sifatnya subjektif, dimana individu merasa sendirian. Kesepian merupakan hal yang bersifat pribadi dan akan ditanggapi berbeda oleh setiap orang, bagi sebagian orang kesepian merupakan yang bisa diterima secara normal namun sebagian orang kesepian bisa menjadi sebuah kesedihan yang mendalam (Tomaka, J., Thompson, s. \& Palacios, 2006). Pada kenyataannya beberapa penelitian menunjukkan bahwa orang yang kesepian bukan tergantung dari kuantitas tetapi tergantung dari kualitas hubungan tersebut. Menurut hasil pengamatan peneliti yang diketahui dari sumber lapangan, lansia sedih dan merasa sepi terpisah dari keluarganya.

Perempuan lebih rentan untuk ansietas dibanding laki-laki karena perempuan lebih mudah dipengaruhi oleh tekanan-tekanan lingkungan. Perbedaan gender juga merupakan salah satu faktor yang mempengaruhi psikologis lansia, sehingga akan berdampak pada bentuk adaptasi yang digunakan (Kaplan \& Sadock, 2007). Hasil pengamatan peneliti menunjukkan perempuan menganggap masalah penyesuaian diri terpisah dengan keluarga seringkali menjadi hal yang sangat sulit. Perempuan lebih 
banyak mengalami stress karena lebih sering terpajan dengan stressor lingkungan dan ambangnya terhadap stressor lebih rentan bila dibandingkan laki-laki.

Tingkat pendidikan juga merupakan hal terpenting dalam menghadapi masalah, semakin tinggi tingkat pendidikan seseorang, semakin banyak pengalaman hidup yang dialaminya, sehingga akan lebih siap dalam menghadapi masalah yang terjadi (Meiner, S. E., 2006). Tingkat pendidikan seseorang dapat mempengaruhi kemampuan untuk mendengar dan menyerap informasi yang didapatkan, menyelesaikan masalah, merubah perilaku serta merubah gaya hidup (Anny, 2012) .

Lansia merasa kesepian karena cukup banyak waktu luang yang tidak dimanfaatkan untuk melakukan kegiatan. Bagi lansia yang tinggal dipanti diberikan aktivitas yang tidak monoton dan didorong untuk bersosialisasi satu sama lain dengan lansia yang lainnya. Hasil pengamatan menunjukkan bahwa lansia yang memiliki banyak waktu luang hanya digunakan untuk tidur.

Kesepian lansia setelah diberikan intervensi didapatkan hasil yang meningkat dan menunjukkan sebagian besar $(75 \%)$ responden mengalami kesepian rendah yaitu responden merasa menjadi bagian dari teman, merasa termasuk orang yang ramah dan mudah bergaul, merasa dekat dengan orang sekitar. Tidak hanya millieu therapy metode kreasi seni yang dapat menurunkan kesepian lansia, dipengaruhi oleh kegiatan lain yang ada di panti yaitu shalat wajib, dzikir dan do'a setiap hari. Namun masih didapatkan lansia yang mengalami kesepian sedang yang ditunjukkan dengan merasa tidak mempunyai tempat berbagi apabila ada masalah, merasa tidak ada seorangpun yang dekat dengannya, dan merasa usulannya tidak ditanggapi oleh orang lain.

Millieu Therapy adalah sebuah perencanaan lingkungan perawatan dimana kejadian dan interaksi setiap hari dirancang secara terapeutik dengan tujuan meningkatkan ketrampilan sosial, membangun rasa percaya diri dan meningkatkan harga diri (Aronson, E., wilson t. D., \& akert, 2010). Millieu Therapy dapat menjadi alat terapeutik yang ampuh untuk mengatur dan mengubah hubungan sosial seseorang dan memberikan hasil yang menguntungkan dalam meningkatkan fungsi yang optimal. Tujuan dari millieu therapy yaitu membantu individu dalam meningkatkan harga diri, meningkatkan kemampuan berinteraksi dengan orang lain, dan menumbuhkan sikap percaya diri pada orang lain (Stuart, G. W., 1998) . 
Metode Kreasi seni membuat gelang dapat dapat menyalurkan kreatifitasnya, menciptakan suatu hasil karya, mengisi waktu luang, dan dapat bekerja sama. Hal ini dibuktikan dengan terjadinya perubahan yang signifikan terhadap kesepian lansia yang mengalami penurunan dalam aspek kognitif, afektif, psikomotor, sesio-emosional, harga diri, dan akan menurunkan kesepian lansia (Yusuf, A., Indarwati, Jayanto, 2010). Agama dapat memberikan pengaruh terhadap kesedihan atau kesepian. Gender, kelas sosial, dan budaya dapat mempengaruhi rohani seseorang terhadap kesedihan dan kesepian (Meiner, S. E., 2006).

Tugas seorang perawat dalam metode kreasi seni yaitu sebagai leader atau bekerja sama dengan orang lain yang ahli dalam bidangnya karena harus sesuai dengan bakat dan minat, serta memberikan kesempatan pada klien untuk menyalurkan/ mengekspresikan perasaannya. Dengan metode kreasi seni membuat gelang lansia dapat melatih kesabaran, ketelitian, dan keuletan, sehingga lansia dapat mengembangkan kemampuan berpikir dan bertindak secara kreatif. Hal ini dibuktikan dengan terjadinya perubahan yang signifikan terhadap penurunan kesepian lansia yang menjadi lebih baik dalam aspek kognitif, afektif, psikomotor, sosio-emosional, dan harga diri.

Berdasarkan hasil observasi saat intervensi pertama, lansia masih merasa malu untuk menanyakan kreasi seni seperti apa yang akan dibuat, merasa tidak cocok dengan teman kelompoknya, merasa sendiri, dan merasa tidak mempunyai tempat berbagi. Pada intervensi pertama ini peneliti memfokuskan agar lansia berani untuk berkomunikasi dan mengungkapkan pendapatnya, dan menghasilkan suatu karya seni. Saat intervensi kedua, lansia sudah berani untuk mengungkapkan pendapatnya, dan berkomunikasi dengan teman kelompoknya. Saat intervensi ketiga, keempat, kelima dan keenam lansia mengalami perubahan yaitu lansia sudah mau membantu teman kelompoknya untuk mengerjakan karya seni, saling berbagi, merasa dekat, tidak merasa dijauhkan dengan yang lain, dan dapat mengisi waktu luang dengan kegiatan yang bermanfaat.

Post test yang dilakukan setelah intervensi dalam penelitian ini, responden yang mendapat intervensi yaitu membuat gelang mengalami penurunan kesepian. Artinya bahwa millieu therapy metode kreasi seni membuat gelang tidak hanya sekedar kreasi seni yang menyenangkan tetapi juga merupakan salah satu metode pengisian waktu luang di panti. Dalam hal ini, perawat memegang peranan penting sekaligus sebagai peluang untuk lebih meningkatkan kompetensi dan kreativitas perawat terutama 
keperawatan jiwa dan gerontik dalam memberikan asuhan keperawatan (Yusuf, Nihayati, Iswari, miranti, Okviasanti, 2016).

\section{Simpulan}

Hasil penelitian ini membuktikan dan dapat menjadi acuan ilmiah bahwa millieu therapy metode kreasi seni membuat gelang dapat menurunkan kesepian lansia. Saran bagi pengelola griya wredha atau care giver lansia di rumah dapat menggunakan milieu therapy untuk mengisi aktivitas rutin harian dan menurunkan tingkat kesepian lansia.

\section{Ucapan Terima Kasih}

Ucapan terimakasih disampaikan kepada Pimpinan UPTD Griya Wredh Surabaya yang telah memberikan ijin penelitian dan seluruh Lansia yang telah berkenan berpartisipasi dalam penelitian ini, semoga bermanfaat bagibpengembangan keperawatan jiwa usia lanjut pada masa yg akan datang.

\section{Daftar Pustaka}

AKBAR, H., D. M. I. (2014). Pengaruh Terapi Aktivitas Kelompok (Sosialisasi) Terhadap Peningkatan Konsep Diri pada Klien Lansia di Panti Sosial Tresna Werdha Gau MAbaji Kab. Gowa. 4, Nomor 1.

Anny. (2012). Pengaruh Latihan Ketrampilan Sosial terhadap Kemampuan Sosialisasi pada Lansia dengan Kesepian.

Aronson, E., wilson t. D., \& akert, R. . (2010). Social Psychology, New York, Prentice Hall.

Brehm, M., Perlman, C. (2002). Intimate Relationship 3 rd edition, USA, McGraw-Hil.

Darmojo, B. D. M., h. had. (1999). Olah Raga dan Kebugaran Pada Lanjut Usia. Jakarta: Balai Penerbit Universitas Indonesia.

Depkes RI. (2005). Pedoman Pelayanan Kesehatan Jiwa Usia Lanjut Edisi 2. Jakarta: Depkes Ditjen Pelayanan Medik.

Kaplan \& Sadock. (2007). Sinopsis Psikiatri: Ilmu Pengetahuan Psikiatri Klinis. Jakarta: Bina Rupa Aksara.

Meiner, S. E., dan A. g. L. (2006). Gerontologic Nursing. Philadelphia: Mosby Elsivier. 
Padila. (2013). Buku Ajar Keperawatan Gerontik. Yogyakarta: Nuha Medika.

RI, M. K. K. R. (2010). Lansia masa kini dan mendatang.

Stuart, G. W., and S. (1998). Buku Saku Keperawatan Jiwa. Jakarta: EGC.

Tomaka, J., Thompson, s. \& Palacios, r. (2006). The relation of social isolation, loneliness, and social support to disease outcomes among the elderly. Journal Aging Health, 18, 359-84.

Weiss, G. L. (1997). The sociologi of health, healing, and illness. Upper Saddler River: Prentice Hall.

WHO. (2010). Proposed working definition of anolder person in africa for the mds project.

Widyati, d., Yusuf, a., Fitriyasari, R. (2014). Peningkatan penerimaan terhadap nyeri kronis, comfort dan kualitas hidup Lansia melalui Acceptance dan Commitment Therapi. Jurnal Ners, 9(1), 252-261.

Yusuf, a., Fitrasari, pk., Nihayati, H. (2015). Buku Ajar Keperawatan Kesehatan Jiwa. Jakarta: SalembaMedika.

Yusuf, A., Indarwati, Retno., Jayanto, A. D. (2010). Senam Otak Meningkatkan Fungsi Kognitif Lansia. Jurnal Ners, 5(1), 79-86.

Yusuf, a., Nihayati, Iswari, miranti., Okviasanti, Ff. (2016). Kebutuhan Spiritual; Konsep dan Aplikasi dalam Asuhan Keperawatan. Jakarta: Mitra Wacana Media Jakarta. 